(REVIEW ARTICLE)

\title{
Hydropower dams and reservoirs and their impacts on Brazil's biodiversity and natural habitats: A Review
}

\author{
Cleber J. R. Alho* \\ Department of Ecology, University of Brasília (retired) Brasília, DF, Brazil.
}

Publication history: Received on 10 June 2020; revised on 24 June 2020; accepted on 25 June 2020

Article DOI: https://doi.org/10.30574/wjarr.2020.6.3.0197

\begin{abstract}
Much of the electric energy produced within the extensive territory of Brazil $\left(8,511,000 \mathrm{~km}^{2}\right)$ comes from large and small reservoirs built to produce hydroelectric power, which flood large natural areas, negatively impacting regional biodiversity. Huge reservoirs originating from Amazon river dams, such as Balbina $\left(2,360 \mathrm{~km}^{2}\right.$, with 26,000 wild animals rescued), in the 1970 s, and Tucuruí $\left(2,430 \mathrm{~km}^{2}, 284,000\right.$ animals rescued, including more than 19,000 howler monkeys), in the 1980s, caused huge losses of natural forest habitats and the consequent decimation of wild fauna. After being rescued, wild animals were released in neighboring areas, whose territories and spaces were already occupied by local animals. In the face of competitive exclusion or because of the principle of xenophobia, these displaced animals ended up dead or experienced truly little success. As well as causing the loss of regional biodiversity, the reservoir creates a vacuum in the previously continuous environment, causing habitat fragmentation. In addition to the Amazon biome, other rivers in different biomes, such as the Pantanal, have also been threatened with the proliferation of dams. There, the hydrological regime influences nutrient cycling, ecological community, phenology, upstream migration of fish and other factors. Fish migrate to the headwaters for spawning behavior that takes place at the headwaters. If they encounter obstacles, such as hydroelectric dams, the migration is interrupted. This review aims to assess the effects on biodiversity of major hydroelectric plants, with their dams and reservoirs, and discusses viable proposals for damage mitigation, environmental compensation, and biodiversity conservation actions.
\end{abstract}

Keywords: Animal rescue; Brazilian biodiversity; Hydroelectric reservoirs; Environmental impacts; Habitat loss; EIA enforcement.

\section{Introduction}

Reservoirs created by dams for hydroelectric plants have expanded across the Amazon and throughout the large Brazilian territory and all South America. This trend, for example, has been documented for the western region of the Amazon, in the highest stretch of the Andes area, where the Amazon River rises [1]. There are more than 150 new dams greater than $2 \mathrm{MW}$ planned for that region.

Hydroelectric plants in Brazil, the largest territory in South America $\left(8,511,000 \mathrm{~km}^{2}\right)$, are responsible for more than $60 \%$ of all the electric energy produced in the country [ANEEL (Agência Nacional de Energia Elétrica). Banco de Informações de Geração. http://www2.aneel.gov.br/aplicacoes/capacidadebrasil/GeracaoTipoFase.asp Last access on 19/05/2020]. Brazil has 8,934 plants for energy (170,241 MW), 217 of which are hydroelectric (102,998 MW), the largest being Itaipu (Paraná River - 14,000 MW, Belo Monte (Xingu River - 11,233 MW), Tucuruí (Tocantins River 8,535 MW), Jirau (Madeira River - 3,750 MW).

Some studies have examined problems and solutions related to hydroelectric power plants in different parts of the world [2]. These also include loss of aquatic habitat, harm to fish communities, among other aquatic species, change in flow regimes, and the overall degradation of landscape [3].

\footnotetext{
${ }^{*}$ Corresponding author: Alho Cleber JR
} 
In addition to the impact of the reservoir itself on the destruction of natural habitats of biodiversity, the construction of a hydroelectric plant also requires the construction of transmission lines, roads and workers' villages, among other effects on the environment, with consequent deforestation and biodiversity disruption. There is documented evidence of socio-economic value for local people, including food and other forest resources of evident benefit to human wellbeing [4].

The negative impacts on biodiversity resulting from the construction of a hydroelectric plant are concentrated in: (1) areas where the infrastructure is installed, plus the works necessary for the project, such as roads, river ports, construction sites, residential villages, dams, dikes, spillways, power houses, etc.; (2) sub-stations of transmission lines, areas of soil borrowing, areas where there will be a density of human population, areas to be flooded by the reservoir and its surroundings, the impacted river section, and other areas; (3) more distant effects where the reflections of the work are felt, including increased human occupation, migration of fish that take long migratory routes; (4) finally, the effects derived from the operation of the hydroelectric plant itself for power generation.

Generally, the planning and execution of hydroelectric plants highlight technical, economic, and financial feasibility for energy generation, relegating environmental issues to a lower level. The main argument is that hydroelectric energy is clean, compared to that produced by coal or oil [World Bank - International Finance Corporation. (2015). Hydroelectric Power - A Guide for Developers and Investors. Washington, DC. (C) International Finance Corporation. https://openknowledge.worldbank.org/handle/10986/22788 Last accessed on 09/06/2020].

The aims of this review are to: (1) Analyze the crucial effects of river dams and their reservoirs on biodiversity and their natural habitats in Brazil, in view of the construction of hydroelectric plants; (2) Check the positive and negative aspects regarding biodiversity conservation, including the irreparable damage caused by the loss of habitats, and how to compensate for the environmental damage, based on the published literature and the author's long experience with this matter; (3) Discuss the administrative and legal aspects of the application of the EIA (Environmental Impact Assessment), its pros and cons in the effective application of compensation for environmental losses and mitigation of the effects on biodiversity.

\section{The realm of energy needs and environmental implications}

The realm of the concern here established is not biodiversity itself in isolation, but also its vision as an ecological community and its dynamic interaction with the ecosystem, in this way emphasizing habitats.

As well as water, energy is the fundamental element of today's society. Hydropower has been one important means by which to provide energy for the growing populations of South American countries [Balza LH, Espinasa R and Serebrisky T. (2016). Energy Needs in Latin America and the Caribbean to 2040. Inter-American Development Bank. https://publications.iadb.org/publications/english/document/Lights-On-Energy-Needs-in-Latin-America-and-theCaribbean-to-2040.pdf Last accessed on 09/06/2020].

This source of energy is always claimed to be clean, in contrast to fossil energy production. It supplies most of the energy needed in Brazil - 65\% - yet there is a vast potential to be developed, particularly in the Amazon region. While hydroelectric potential has been socioeconomically attractive, the environmental cost has also been extremely high, with damage to biodiversity. Additionally, environmental impacts with biodiversity degradation are intricately linked to socioeconomic impacts for local people living within the area of influence of the effects generated by the hydroelectric plant. The overall importance of freshwater for society should also be emphasized, including pure water supply, fisheries, and other benefits.

Thermoelectric energy does not exceed $7.5 \%$ of the Brazilian electricity production, and this number is only reached when all the plants are in operation in the country. Thermoelectric plants supply industries and act as sources of reserve in cases of energy crisis. This energy is produced by a plant that generates heat resulting from the burning of solid, liquid, or gaseous fuels, such as oil and, in some cases, biomass, like sugar cane bagasse.

Nuclear energy accounts for about 3\% of energy generation in Brazil. There are three plants in operation: Angra 1, Angra 2, and more recently Angra 3, installed in the municipality of Angra dos Reis, in the state of Rio de Janeiro, with a generation potential of 3,000 megawatts. Nuclear energy has a serious problem of radioactive waste, that is, the remains of nuclear fission that is the source producing energy.

The scientific literature has pointed out the importance of freshwater ecosystems and their associated biodiversity, due to the increasing human use of land that has affected those ecosystems along all river systems on the planet $[5,6,7]$. 
The formation of a reservoir, originating from damming a river for hydroelectric power generation, has impacts on native fauna, including habitat loss and ecological changes among wildlife communities [8]. Besides that, environmental changes from a lotic to lentic system directly affect animals of semi-aquatic and aquatic habits, such as some representatives of the invertebrates, reptiles, birds, mammals, and fish [9]. With the filling of the reservoir, what used to be a forest suddenly turns into a lake [10]. This change increases the amount of water that evaporates and, consequently, impacts climatic factors: total rainfall, humidity, and temperature. The astonishing number of more than 19,000 howler monkeys rescued, during the filling of the Amazonian Tucuruí reservoir, is one of those pieces of evidence on the impacts on biodiversity [11].

\section{Case study 1: impacts of small hydroelectric power plants}

Small hydropower plants (SHPs) have proliferated in many countries, with an estimation that 82,891 plants are operating or under construction in 150 countries and that another 181,976 new plants may be installed [12]. This study reveals a ratio of 11 SHPs for every one large hydropower plant, under global focus, and this number is estimated to triple if all potential generation capacity is developed.

The SHPs are distributed throughout the territory of Brazil, generating about 7,000 MW for the country's electrical system, according to information from the National Electric Energy Agency [ANEEL (Agência Nacional de Energia Elétrica) (2017). Pequenas Centrais Hidrelétricas permitirão acréscimo de $7.000 \mathrm{MW}$ ao sistema. https://www.aneel.gov.br/sala-de-imprensa-exibicao/-/asset_publisher/XGPXSqdMFHrE/content/pequenas-

centrais-hidreletricas-permitirao-acrescimo-de-7-000-mw-ao-sistema/656877 Last accessed on 09/06/2020]. From the Government's strategic point of view, SHPs are more viable than a large plant; moreover, they are distributed in the national territory, generate local jobs, and do not require large transmission lines. There are about 500 small hydroelectric plants throughout Brazil. An average of 33 SHPs were constructed per year from 2001 to 2016, a growth rate 14 times as fast as that witnessed in the 1990s. Brazilian private landowners were stimulated to invest in constructions of SHPs on their land, motivated by new policies and regulations [13].

Building the SHP basically depends on conducting an Inventory Study, which will analyze the hydraulic potential of the river where it will be installed and on a basic project, which is nothing more than a technical detail. The project's analysis and approval is the responsibility of ANEEL [ANEEL (Agência Nacional de Energia Elétrica) (2017). Pequenas Centrais Hidrelétricas permitirão acréscimo de 7.000 MW ao sistema. https://www.aneel.gov.br/sala-de-imprensa-exibicao//asset_publisher/XGPXSqdMFHrE/content/pequenas-centrais-hidreletricas-permitirao-acrescimo-de-7-000-mw-aosistema/656877 Last accessed on 09/06/2020]. It turns out that several countries, including Brazil, have approved policies that reduce the need for environmental planning and regulation for SHPs [14].

In Brazil, the power of the SHP must be between 1 and $30 \mathrm{MW}$. However, by force of federal laws $(10,438$ of 2002 and 13,360 of 2016) the upper limit was increased to 50 MW [ANEEL (Agência Nacional de Energia Elétrica). Banco de Informaç̧̃es de Geração. http://www2.aneel.gov.br/aplicacoes/capacidadebrasil/GeracaoTipoFase.asp Last access on 19/05/2020]. The aggravating factor in the case of SHPs is that they are exempt from the EIA, requiring only the preparation of a simplified environmental study, which in most cases does not indicate all impacts. Brazilian rivers are turning into stairways of small lakes with the sole function of generating energy, damaging biodiversity, the landscape, and the development of other economic activities [15,1,13,12].

Although SHPs do not flood large areas, unlike large hydroelectric reservoirs, they do prevent the movement of fish upstream, in addition to guiding the flow of water to the powerhouse, interfering with the normal flow and water quality of rivers at their headwaters. Consequently, environmental impacts of SHPs include those associated with the dam's construction and land flooding by the reservoir, with loss of biodiversity, and potential habitat fragmentation, as well as post-construction alteration to flow regime and water quality $[15,1,13,12]$. A set of SHPs in the same hydrographic basin can cause social and environmental damage comparable to that of large hydroelectric plants [16].

Focusing on the Pantanal biome, for example, there are more than 100 small hydroelectric plants planned, mainly for the northern part of the plateau, where the rivers that feed the Pantanal flatland rise [ANEEL (Agência Nacional de Energia Elétrica) (2016). Quadro de acompanhamento de autorizações das PCHs. Ministério das Minas e Energia. http://www.aneel.gov.br/aplicacoes/autorizacoes/default_aplicacao_acompanhamento.cfm Last accessed on 09/06/2020][15]. This biome is a wetland $\left(150,355 \mathrm{~km}^{2}\right)$, located in the center of South America, mostly in Brazil $\left(140,000 \mathrm{~km}^{2}\right)$, in the upper Paraguay River, touching Bolivia and Paraguay. In the Pantanal, the seasonal flux of the rivers is a fundamental ecological element for regional biodiversity. 
Habitat alteration and deforestation within the Pantanal have affected terrestrial and aquatic habitats and their associated wildlife [7]. There are important fish species with ecological and socioeconomic values in the biome that migrate to the headwaters for spawning behavior. The spawning takes place at the headwaters, the eggs are carried by the water downstream and the young fish grow in the productive waters of the floodplain. At the beginning of the rainy season, the fish go up the rivers to spawn. If they encounter obstacles, such as hydroelectric dams, the migration is interrupted. As a wetland ecosystem, the Pantanal is characterized by an indistinct, but always changing, boundary between aquatic and terrestrial environments [17]. The seasonal flooding system causes an annual biogeochemical cycle of influx of nutrients, particles, microorganisms, and invertebrates, which forms a dynamic ecosystem with a mosaic of habitats, which sustains biological diversity $[17,18,19]$.

The published literature identified different environmental impacts caused by SHPs [20,12,22], which include: effects on fish reproductive strategies and on fish ecological communities [21,24]; decrease in macroinvertebrate richness and community structure in downstream habitats and algae community [23]; and the fragmentation of biodiversity habitats [24]. From the international viewpoint, there is global proliferation of small hydropower plants [12]. Adverse effects of 23 SHPs were studied in the Czech Republic by traditional benthological and ichthyological techniques, showing that most SHPs took a high percentage of the stream discharge [21]. This study pointed out that the presence of SHP was an important migration barrier for resident fish.

\section{Case study 2: impacts of large hydroelectric power plants}

Large hydroelectric power (LHP) plants in tropical biomes pose a range of major threats to terrestrial and freshwater biodiversity. Most of the adverse impacts on biodiversity come from the environmental impact assessment of the Belo Monte Hydroelectric Power Plant on the Xingu River, Amazon region, which was attended by the author, as part of the EIA studies team. For this objective, a team of researchers and field assistants (including the participation of the author) established and performed the following steps: (1) made an environmental and biological diagnosis of the region; (2) based on this diagnosis and the extent and complexity of the works for the implementation of the hydroelectric enterprise, the prognosis of impacts was made; (3) identified and classified the multiple impacts for the various phases of the hydroelectric enterprise; (4) finally established the criteria for implementing programs on environmental loss compensation and on mitigating the different impacts.

The results of the fieldwork identified six main types of forest vegetation cover in the region with which the fauna was associated. In the study area, 28 plant species, officially threatened with extinction, were identified. These species were affected by the enterprise. The abundance of trees with a minimum of five centimeters in diameter at breast height was estimated to be near 200 million, many of them expected to be lost due to the enterprise (unpublished partial report of EIA-Belo Monte).

The impacts observed in the flora have devastating effects on the macrofauna of invertebrates, notably insects, with local extinction, fragmentation of populations, and the proliferation of species that take advantage of the disturbance. There was proliferation of disease vectors (malaria and leishmaniosis, among others) and hematophagous insects inconvenient to man, such as flies of the Tabanidae family.

The Amazon turtle Podocnemis expansa depends heavily on environmental integrity and river flow seasonality to fully perform its communal nesting behavior [25,26]. During high water of the Xingu River, male and female turtles normally feed in lakes adjacent to the river. During the dry season, when huge sandy beaches appear along the river (Juncal, Cipó Pitanga and Embaubal beaches), adult turtles migrate from lakes, connected to the river, to select nesting areas on that river beach. The migration of adult males and females coincides with the ebbing regime of the river, the nesting season being synchronized with lowest water $[25,26]$. This communal reproductive behavior displayed by the Amazon turtle involves seven phases: (1) turtles arriving from the lakes concentrate for several days, in their hundreds, in shallow water, in front of the selected nesting beach, prior to landing; (2) turtles reach the sandy beach, after about 7-10 days; (3) animals walk around or explore the beach; (4) they excavate the nest; (5) they lay eggs, following a stereotyped behavior; (6) they fill and camouflage the nest; (7) they return to the water. Thus, this evolutionarily old species has an elaborate nesting behavior that is very susceptible to small disturbances. The proven presence of large numbers of turtles that spawned on the beaches of the Xingu River was severely impacted by the multiple effects of the hydroelectric plant.

Diagnosis with ichthyofauna showed that 28 species were endemic to the Xingu, and fish in the region suffer from many threats. An example of the impact of hydroelectric power on fish and fishing is the threat to ornamental fish, collected for the trade of aquarium fish, and many of these are endemic to the Xingu region where the dam and reservoir were 
constructed. This is the case of the acari-zebra Hispancistrus zebra, of high value on the market (unpublished partial report of EIA-Belo Monte).

Many other LHPs such as Itaipu, in the Paraná River, between Brazil and Paraguay, with a 1,350 $\mathrm{km}^{2}$ reservoir, contributed to the disappearance of the local Atlantic Rainforest flora and fauna [27]. The building work to carry out the hydroelectric plant, with consequent deforestation, was deleterious for local biodiversity. When the Itaipu dam lake was formed, for example, 30,000 animals were rescued and taken to a reserve area. Many died from not adapting to the new habitat. In addition to deforestation, affecting the local fauna, there was the effect on $170 \mathrm{~km}$ of the Paraná River, including the submersion of the Sete Quedas fall, disrupting the natural flow of that large river, with consequent impact on fish and other aquatic organisms [27].

Following on from the impacts on biodiversity during the construction of the hydroelectric plant, the subsequent impacts must also be considered during the years of operation of the project. The effect on isolated large-bodied assemblages of terrestrial and arboreal vertebrates, mammal, bird and tortoise species, over the 26 years of operation of the Balbina hydroelectric dam, whose reservoir flooded 3,360 km2 of primary forests of the Brazilian Amazon, was evaluated [8]. This study showed that approximately $70 \%$ of all native medium-to-large vertebrate populations surveyed, living on isolated islands of the flooded reservoir area, were predicted to disappear due to local extinctions within the reservoir.

Only 25 islands ( $0.7 \%$ of the 3,546 larger islands) retained four-fifths of a full complement of vertebrate species. These results highlighted the long-term impact of the Balbina dam on forest biodiversity within insular forest patches. Even though a species-rich vertebrate assemblage was retained on a few large islands, most islands failed to provide sufficiently large areas of high-quality habitat for the terrestrial/arboreal vertebrate fauna. Although the larger islands maintained great diversity of vertebrates sampled in this study $[8,28]$ the smaller islands suffered high biodiversity losses due to the fragmentation and disappearance of ecological resources essential for these vertebrates.

The expansion of areas flooded by large reservoirs of hydroelectric dams in the Amazon does not necessarily increase the population of giant otters, since the populations of these aquatic mammals do not expand into the new habitats created by flooding, as this expansion is impeded by the low quality of the habitats selected by the otters [29].

An investigation into how Amazon primates respond to the environmental intervention of the Balbina hydroelectric plant, 21 years after its construction, showed that there are different responses to habitat disturbance, depending on the degree of habitat isolation and the species of primate [30]. Tree density and vertical stratification were the most significant explanatory variables of primate composition and richness.

Additionally, a study aimed at predicting the extinction of species of wild animals in the Amazon rainforest, living on isolated islands due to the flooding of the Balbina hydroelectric plant, showed that forest area, home range and dispersal ability were the best predictors of occupancy, and fewer than $2 \%$ of all 3,546 islands surveyed were likely to harbor at least $75 \%$ of all wild species [8]. The barrier effect is one of the main causes in altering the remaining forests on the islands formed by the flooding of the Balbina hydroelectric plant, 26 years after the flooding of the reservoir, with the effects of habitat loss and habitat insularization on tree assemblages $[30,7]$.

Anthropogenic alteration of habitats changes the natural composition of the herpetofauna, modifying the diversity and species richness of amphibians and lizards of the Neotropic region [31].

Small wild mammals from the Amazon also show their response to habitat degradation caused by the flooding of the Balbina reservoir, 28 years after the flood. Species richness was best predicted by island area and isolation, with small islands ( $<15 \mathrm{ha}$ ) harboring an impoverished nested subset of species, whereas large islands ( $>200 \mathrm{ha}$ ) and continuous forest sites exhibited similarly high species richness. Forest-dependent species showed higher local extinction rates and were often either absent or persisted at low abundances on small islands, where non-forest-dependent species became hyper-abundant [32]. The disappearance of species of birds from the Amazon rainforest, on the islands formed by the filling of the reservoir of the Balbina hydroelectric plant, after 25 years of isolation, showed that large birds with insectivorous habits associated with tree trunks, large bodied trunk insectivores and terrestrial frugivore/faunivores were strongly sensitive to forest fragmentation, as further evidence of the effect on biodiversity [33]. Furthermore, the isolation of the Balbina islands is evidenced in the local extinction of bees of Amazonian orchids - after 26 years of isolation of these islands by the flooding of the reservoir. A study showed that of the 25 species of bees monitored in the continuous forests, insular forest area explained only $10 \%$ of the total variation in bee species richness [34]. 
Another study on the forest of isolated islands formed by the Balbina reservoir showed the instability of trees in the ecological communities of these islands, since that mega-dam created highly fragmented archipelagos, affecting biodiversity and ecosystem functioning in remnant forest isolates [35,36]. Effects of habitat insularization on arthropod fauna were accessed to investigate how dung beetle assemblages respond to 30 years of post-isolation history in Amazon forest islands within the Balbina hydroelectric reservoir [37]. This study concluded that 34 dung beetle species and 15 genera were sampled and one third of all islands had been entirely defaunated of dung beetles in terms of overall occupancy $[37,38]$.

Manso is a medium-sized hydroelectric plant (212 MW, with a reservoir of $420 \mathrm{~km}^{2}$ ), located in an ecologically strategic environment, connecting the highlands of the upper Paraguay River basin to the huge lowland biome that is the Pantanal. The Manso River, located in the highlands of Chapada dos Guimarães, is a tributary of the left bank of the Cuiabá River, which in turn discharges its waters into the Paraguay River, which feeds the Pantanal wetland. This region is the domain of the Cerrado (savanna) biome, with clear climatic seasonality, whose rains occur from October to April, with greater intensity between December and March. The fauna studied in the region of influence of the Manso hydroelectric plant revealed high species richness, supported by the diversity of habitats of the Cerrado-Amazonia ecotone region [39]. Field studies detected species adapted to the interior of forested habitats, as in the case of anurans of the genera Colostethus and Anolis. These species are extremely sensitive to habitat changes under the impacts caused by the hydropower plant. Among birds, species susceptible to habitat disturbance were detected, such as Tinamus tao, Leucopternis albicollis, Daptrius americanus, Charistopiza eucosma, and others. Some wild mammal species, listed as threatened by extinction, were detected during field work, such as Priodontes maximus, Myrmecophaga tridactila, Chrysocyon brachyurus, Leopardus pardalis, Panthera onca and others [39]. An interesting fact was noted in relation to prehensile-tailed-porcupine Coendou prehensilis. During the exhaustive studies of preliminary field censuses, the important occurrence of these animals was detected in forested habitats. During the filling of the reservoir, however, the number of this rescued species far exceeded what the diagnostic fieldwork indicated.

In the Cerrado biome, the reservoir created by the Tocantins River dam, Serra da Mesa hydroelectric, showed changes in anuran species richness and abundance, under the effect of ecosystem losses and habitat fragmentation, mainly of forested habitats in valleys, showing rapid decline of that indicator of biodiversity, during and after flooding. [9].

From the beginning of hydropower works, it has been observed that the wild animal densities increase suddenly, in those neighboring areas, but they later decrease, due to intense competition for ecological resources, with active defense of marked home ranges and territories by resident fauna [39]. This same process also occurs when the fauna affected locally by the disturbance of the infrastructure of the work, mainly during the filling of the reservoir, are rescued and released in neighboring areas, already occupied by the resident fauna $[11,40]$. In the case of the flooding of more than $2,000 \mathrm{~km}^{2}$ of the Tucuruí reservoir, more than 19,000 howler monkeys were rescued when the forest was being flooded. As the water rose, the animals threw themselves into the water and were captured for rescue, as observed in the case of Tucuruí and many other large hydroelectric plants [11,40,39,31]. During the filling of the Tucuruí reservoir in the late 1970s, around 280,000 animals were rescued by the Curupira operation, including 28,700 sloths (genus Bradypus), 11,900 real sloths (genus Choloepus), 9,700 armadillos (family Dasypodidae), 9,300 prehensile-tailed porcupines (genus Coendou), 5,800 agoutis (genus Dasyprocta), 3,700 giant anteaters (genus Myrmecophaga), 19,500 howler monkeys (genus Allouata), 2,500 capuchin monkeys (family Cebidae), 48,600 terrestrial tortoises (genus Chelonoidis) and 20,900 iguanas (genus Iguana), among other wild forest animals [11, 41, 42].

The Tocantins River, where the Tucuruí reservoir is located, is one of the main tributaries of the Amazon River and has its springs in the highlands of the Brazilian plateau, covered by the Cerrado (savannah). Endemic fish species occur in this river such as: piranhas Serrasalmus geryi and S. eigenmanni and other species like aracus Leporinus affinis and $L$. taeniatus, the ray Potamo trygonhenley, and others [41]. Reservoir water is generally more stagnant than the normal flux observed in the river water. The change from the lotic to the lentic environment favors the proliferation of fish from the latter environment, harming rheophilic fish species, thus altering the fish community. A decrease was observed in the abundance of fish species with detritivorous, herbivorous and insectivorous feeding habits in the reservoir. On the other hand, species with another feeding strategy, such as predators, omnivorous and planktivorous fish, show increased abundance $[41,6]$.

The response of wild birds, living on 36 islands, to the fragmentation of the Amazon rainforest, 22 years after the formation of the Tucuruí reservoir, showed that the rate of bird species loss as a function of island area reduction was higher for forest bird species specialists than for habitat generalists [42]. Predicted decay of avian species richness, induced by forest loss, was affected by the degree of habitat specialization of the bird species. Still, on the Tucuruí reservoir, a study showed that alterations at the edges of forest fragments affect plant communities that suffer increases in tree damage and death, and decreases in seedling recruitment [43]. 
During the operation of the hydroelectric plant, frequent switching on-and-off of turbines causes effects on riverbed scour, impacting fish. In fact, in the Tucuruí hydroelectric plant, downstream from the dam, a decrease in abundance of fish species was observed, mainly due to the regulation of river flow, which greatly disturbs the annual feeding and reproductive cycles of fish [6]. This fieldwork pointed out that the sharp decline in fish abundance after closing the Tucuruí dam is due to the daily downstream fluctuation of the water level and, especially, the weekly variation in river level as a function of the flow of water in turbines to attend different hours of energy production. The change in the volume of water disrupts all aquatic life, especially on the banks, which face periods of drought and flooding [6]. The greatest demand for electricity, which is in the early evening of each day, as well as lower demand by the industries on weekends, leads to a regulation of the amount of water passing through the turbines that is released into the river, causing a small increase in river level every night, and a reasonable decrease in level every weekend.

There is low participation of the local human populations, affected by the hydropower enterprise, in the process of licensing and construction of the plants [46]. Usually, local participation is used more to comply with the bureaucratic protocol. The logic of political and economic power prevails over environmental issues. However, the impacts on biodiversity are observed in different hydropower plants (Jamari River dam, in the state of Rondônia - Samuel hydroelectric plant, in the Brazilian Amazon, whose lake flooded $540 \mathrm{~km}^{2}$ of forest; the Xingu River dam - Belo Monte hydroelectric plant, also in the Amazon, with more than 200,000 animals rescued, among many other hydroelectric plants $[44,45,37]$.

\section{Discussion}

In principle, any major energy plant that has a significant impact on the environment must be evaluated by the EIA method. This provides a synthesis of the challenge of measuring and interpreting the multiple impacts on environmental values, particularly biodiversity, in search of a better equilibrium between socio-economic priority and nature conservation $[47,1,46]$. In the case of Brazil, the EIA has well-defined legislation, which is included in the federal constitution, followed by complementary legislation and norms. The biggest problem arises in the real implementation of these programs, especially when large construction companies take over nearly all of the work. In fact, the licensing of works with major impacts, such as hydroelectric plants, should incorporate robust analyses with strong technicalscientific content $[47,14]$. In addition to the impacts identified because of the hydroelectric construction, there are other important effects arising from human expansion on site, with more deforestation, rural endemic diseases, hunting, and other degradations to biodiversity $[27,46,31,32]$. Given that climate and ecology are inextricably linked, assessing the effects of energy technologies requires one to consider their full suite of global environmental concerns $[46,48]$. The reservoirs generate gases, especially methane, creating the link with the concern for climate change; collectively, reservoirs created by dams are an important source of greenhouse gases released into the atmosphere [51].

There is always an identifiable controversy about the faithful compliance with the technical-scientific protocol required by the EIA. As this task requires a trained and competent team to perform this protocol, often in certain countries in South America, and especially in some more remote places, this requirement of technical-scientific competence is not completely fulfilled and the protocol becomes a mere bureaucratic procedure to comply with local legislation and obtain the approval of the work. Long experience in Brazil with environmental impact assessments (EIA) of medium and large hydroelectric plants shows that previous studies on impact identification, evaluation of the magnitude of these impacts, and establishment of programs for environmental compensation in the case of irreparable losses, and mitigation in other cases, are very well conducted by qualified personnel, usually from the academic and research institutions. The biggest problem arises in the real implementation of these programs, especially when large construction companies almost always take over the work. In fact, the licensing of major works, such as hydroelectric plants, should incorporate robust analyses with strong technical-scientific content.

In the implementation of the EIA, the technical team that performs the work in the field normally seeks to comply with the "Term of Reference" of the Government's environmental agency which, in the case of Brazil, is IBAMA (Brazilian Institute of Environment). However, the environmental indicators for biodiversity to be designated are decided by the study's executors, but not always in harmony in the choice. These indicators, which can be quantitative or qualitative, must express the state of the environment when planning the hydroelectric plant (prognosis), describe its operation and allow changes in the environment to be estimated during the construction phase (diagnosis and action plan for mitigation and compensation impacts), resulting from the action promoted by the enterprise.

The evaluation of the efficiency of the fish transposition mechanism by means of the construction of fish ladders besides the dam wall, in tropical environments, has been contested, in contrast to the greater efficiency in temperate countries. Work in this direction carried out in Brazil has shown that the ladder is selective, and only fish species of small size can 
go up it [49]. The oldest fish stairs, such as the Porto Primavera hydroelectric plant, on the upper Paraná River, have shown success at least for one important species of fish - the curimba Prochilatus lineatus [50].

A call for more 'sophisticated and holistic hydropower planning" in the Amazon, Congo and Mekong is expressed by Winemiller et al. [14], stressing that "these very complex ecosystems are being managed in a highly reductionist manner - a socio-environmental disaster is the natural future scenario of current actions". This article, signed by multiple authors, emphasizes the massive construction plan for hydroelectric dams in the rivers of the Brazilian Amazon, whose implementation causes irreversible environmental and socio-economic damage.

It is common to observe in the context of the largest hydroelectric plants the presence of human settlements in clear social conflict. There is an official settlement, established by large construction companies, for example, the workers' village, with medical service, sanitary infrastructure, and other benefits. Nearby, there are human clusters, in extreme poverty, without sanitary infrastructure, formed by migrants waiting for a job opportunity. Drastic outbreaks of rural endemics such as malaria, yellow fever, and leishmaniosis, etc. are noted.

Given the importance of hydroelectric power for the desired energy supply, the social acceptability of the risk is indicated and accepted. In this case, the magnitude, extent, scale and importance of the impact come up against the same socio-economic benefits of the implementation of the work, since the political decision favors the hydroelectric plant.

The Legislation on the EIA is supposed to give consistency to the actions to achieve environmental objectives. The problem is that every country in South America, or even every region of each country, has its own legislation with different contexts and interests. The case of Brazil's legislation, which slows down the rules to implement SHPs, thus encouraging landowners to create hydroelectric plants, is one of these contrasts.

A significant issue that is observed in the implementation phase of the hydroelectric infrastructure work, and even in the post-work phase of the plant's operation, is the consequent transgression of rules established by the EIA for zoning and areas designated to be protected. These zoning ordinances are necessary in view of the increased number of people who arrive, attracted by the hope of employment. For example, the Belo Monte hydroelectric plant on the Xingu River attracted about 100,000 people within 3-4 years, including job seekers and their families.

A suggestion to mitigate the impacts that occur during the operation of the hydroelectric plant, due to frequent switching on-and-off of turbines, would be to manage these increases and decreases in generation capacity of turbines due to energy demand, within the possibility of the plant. This would allow turbine switching to slow down, increasing the length of a reflux wave, reducing the speed of water level and the length of the stretch of river that is in danger.

A problem that arises because of the filling of the hydroelectric reservoir is the huge number of animals rescued, as shown here in this study. Usually the entrepreneur and the institution in charge of this activity rescues the animals, because, for example, a primate or other arboreal animal that throws itself into the water that floods the forest must be rescued to avoid a bad press for the whole enterprise.

At the Manso hydroelectric plant, a procedure was created to use the rescued fauna [39]. A structure was installed in a building suitable for this purpose, which was called the Screening and Quarantine Center. A letter was addressed to more than 150 academic and research institutions offering wild animals, emphasizing scientific use. The rescued animals were then screened, treated in quarantine and made available for the benefit of the institutions.

\section{Conclusion}

Hydropower plants, for example in the Amazon biome, interrupt and fragment the immense extent of the forest cover, which is an important predictor for species richness and functional biodiversity. The construction works of hydroelectric plants, small or large, have multiple impacts on biodiversity and habitat. Many of these impacts can be identified and, for each one, the degree of importance must be measured, depending on the development of the work, over the long period of operation of the plant, in order to develop programs to mitigate these impacts. However, there are impacts that are irreversible, irreparable, and only one environmental loss compensation program applies. This is the case with the enormous impact of the area flooded by the reservoir. The environmental loss compensation program, in Brazil, is generally executed by establishing a protected area that ideally contains the ecological and biological elements lost by the formation of the reservoir.

The EIA allows ways to minimize impacts to be analyzed, developed, and implemented. Environmental restrictions are becoming more widespread; non-governmental organizations are increasingly active, and Brazilian environmental 
legislation is good and has been implemented. Even so, there are few qualified staff to analyze and monitor the demands of these studies, and there is strong political influence on decisions that should primarily be technical and scientific.

\section{Compliance with ethical standards}

\section{Acknowledgments}

I am grateful to my wife, Celina Alho, who assisted me during all phases of this research work.

\section{Disclosure of conflict of interest}

The author declares that he has no conflict of interest regarding financial, commercial, legal, or professional relationships with organizations or persons that could influence this research.

\section{References}

[1] Finer M and Jenkins CN. (2012). Proliferation of hydroelectric dams in the Andean Amazon and implications for Andes-Amazon connectivity. PLoS One, 7(4), e35126.

[2] Koç C. (2012). Problems and Solutions Related to Hydroelectric Power Plants Constructed on the Buyuk Menderes and the West Mediterranean Basin, Energy Sources, Part A: Recovery, Utilization, and Environmental Effects, 34(15), 1416-1425.

[3] Zdankus N, Vaikasas S and Sabas G. (2008). Impact of a hydropower plant on the downstream reach of a river, Journal of Environmental Engineering and Landscape Management, 16(3), 128-134.

[4] Alho CJR and Silva JSV. (2012). Effects of severe floods and droughts on wildlife of the Pantanal wetland (Brazil) - A Review. Animals, 2, 591-610.

[5] Dudgeon D, Arthington AH, Gessner MO, Kawabata ZI, Knowler DJ, Lévêque C, Naiman RJ, Prieu-Richard AH, Soto D, Stiassny MLJ and Sullivan CA. (2006). Freshwater biodiversity: Importance, threats, status and conservation challenges. Biological Reviews, 81(2), 163-182.

[6] Alho CJR, Reis RE and Aquino PPU. (2015). Amazonian freshwater habitats experiencing environmental and socioeconomic threats affecting subsistence fisheries. Ambio, 44, 412-425.

[7] Alho CJR, Mamede SB, Benites M, Andrade BS and Sepúlveda JJO. (2019). Threats to the biodiversity of the Brazilian Pantanal due to land use and occupation. Ambiente \& Sociedade, 22, 1-22.

[8] Benchimol M and Peres CA. (2015a). Predicting local extinctions of Amazonian vertebrates in forest islands created by a mega dam. Biological Conservation, 187, 61-72.

[9] Brandão RA and Araújo FB. (2008). Changes in Anuran Species Richness and Abundance Resulting from Hydroelectric Dam Flooding in Central Brazil. Biotropica, 40(2), 263-266.

[10] Benchimol M and Peres CA. (2015b). Edge-mediated compositional and functional decay of tree assemblages in Amazonian forest islands after 26 years of isolation. Journal of Ecology, 103(2), 408-420.

[11] Alho CJR. (1984). Fauna em extinção: Emoção não basta. Revista Brasileira de Tecnologia, Brasília, 15(5), 5-12.

[12] Couto TBA and Olden JD. (2018). Global proliferation of small hydropower plants - science and policy. Frontiers in Ecology and the Environment, 16(2), 91-110.

[13] Latini JR and Pedlowski MA. (2016). Examinando as contradições em torno das Pequenas Centrais Hidrelétricas como fontes sustentáveis de energia no Brasil. D e MA - Desenvolvimento e Meio Ambiente, 37 (Edição Especial Nexo Água e Energia).

[14] Winemiller KO, McIntyre PB, Castello L, Fluet-Chouinard E, Giarrizzo T, Nam S, Baird IG, Darwall W, Lujan NK, Harrison I, Stiassny MLJ, Silvano RAM, Fitzgerald DB, Pelicice FM, Agostinho AA, Gomes LC, Albert JS, Baran E, Petrere Jr. M, Zarfi C, Mulligan M, Sullivan JP, Arantes CC, Sousa LM, Koning AA, Hoeinghaus DJ, Sabaj M, Lundberg JG, Armbruster J, Thieme ML, Petry P, Zuanon J, Torrente Vilara G, Snoeks J, Ou C, Rainboth W, Pavanelli CS, Akama A, van Soesbergen A and Sáenz L. (2016). Balancing hydropower and biodiversity in the Amazon, Congo, and Mekong. Science, 351(6269), 128-129.

[15] Calheiros DF, Arndt E, Rodriguez EO and Silva MCA. (2009). Influências de usinas hidrelétricas no funcionamento hidro-ecológico do Pantanal matogrossense - Recomendações. Documentos, Brasília, 102, 1-21. 
[16] Ruocco AMC, Portinho JL and Nogueira MG. (2019). Potential impact of small hydroelectric power plants on river biota: a case study on macroinvertebrates associated to basaltic knickzones. Brazilian Journal of Biology, 79(4), 722-734.

[17] Alho CJR. (2005).The Pantanal. In: Fraser LH and Keddy PA (Eds.) The World's Largest Wetlands — Ecology and Conservation. Cambridge University Press, New York, 203-271.

[18] Alho CJR and Silva JSV. (2012). Effects of severe floods and droughts on wildlife of the Pantanal wetland (Brazil) - A Review. Animals, 2, 591-610.

[19] Ferreira LV, Neckel-Oliveira S, Galatti U, Fáveri SB and Parolin P. (2012). Forest structure of artificial islands in the Tucuruí dam reservoir in northern Brazil: a test core-area model. Acta Amazonica, 42(2), 221-226.

[20] Anderson EP, Freeman MC and Pringle CM. (2006). Ecological consequences of hydropower development in Central America: impacts of small dams and water diversion on neotropical stream fish assemblages. River Research and Applications, 22(4), 397-411.

[21] Kubecka J, Matena J and Hartvich P. (1997). Adverse ecological effects of small hydropower. Regulated Rivers: Research \& Management, 13(2), 101-113.

[22] Jesus T, Formigo N, Santos P and Tavares G. (2004). Impact evaluation of the Vila Viçosa small hydroelectric power plant (Portugal) on the water quality and on the dynamics of the benthic macroinvertebrate communities of the Ardena River. Limnetica, 23, 241- 255.

[23] Cortes RMV, Ferreira MT, Oliveira SV and Godinho F. (1998). Contrasting impact of small dams on the macroinvertebrates of two Iberian mountain rivers. Hydrobiologia, 389, 51- 61.

[24] Gido KB, Whitney JE, Perkin JS and Turner TF. (2016). Fragmentation, connectivity and fish species persistence in freshwater ecosystems. In: Closs GP, Krkosek M and Olden JD (Eds). Conservation of freshwater fishes. Cambridge University Press, Cambridge, UK, 292-323.

[25] Alho CJR and Pádua LFM. (1982). Sincronia entre o regime de vazante do rio e o comportamento de nidificação da tartaruga-da-Amazônia Podocnemis expansa (Testudinata: Pelomedusidae). Acta Amazonica, 12(2), 323-326.

[26] Alho CJR. (1985). Conservation and management strategies for commonly exploited amazon turtles. Biological Conservation, 32, 291-298.

[27] Ziober BR and Zanirato SH. (2014). Actions to safeguard biodiversity during the building of the Itaipu binacional hydroelectric plant. Ambiente \& Sociedade, XVII(1), 59-78.

[28] Benchimol M and Peres CA. (2015c). Widespread Forest Vertebrate Extinctions Induced by a Mega Hydroelectric Dam in Lowland Amazonia. PLoS One, 10(7), e0129818.

[29] Santos GM. (1995). Giant otter population responses to habitat expansion and degradation induced by a mega hydroelectric dam. Biological Conservation, 174, 30-38.

[30] Benchimol M and Venticinque EM. (2014). Responses of Primates to Landscape Change in Amazonian Landbridge islands-a Multi-scale Analysis. Biotropica, 46(4), 470-478.

[31] Palmeirim AF, Vieira MV and Peres CA. (2017). Herpetofaunal responses to anthropogenic forest habitat modification across the neotropics: insights from partitioning $\beta$-diversity. Biodiversity and Conservation, 26 , 2877-2891.

[32] Palmeirim AF, Vieira MV, Benchimol M and Peres CA. (2018). Small mammal responses to Amazonian forest islands are modulated by their forest dependence. Oecologia, 187, 191-204.

[33] Silva, MA, Anciães M, Henriques LMP and Peres CA. (2016). Patterns of local extinction in an Amazonian archipelagic avifauna following 25 years of insularization. Biological Conservation, 199, 101-109.

[34] Storck-Tonon D and Peres CA. (2017). Forest patch isolation drives local extinctions of Amazonian orchid bees in a 26 years old archipelago. Biological Conservation, 214, 270-277.

[35] Jones IL, Peres CA, Benchimol M, Bunnefeld L and Dent DH. (2019). Instability of insular tree communities in an Amazonian mega-dam is driven by impaired recruitment and altered species composition. Journal of Applied Ecology, 56(3), 779-791.

[36] Bueno AS and Peres CA. (2019). Patch-scale biodiversity retention in fragmented landscapes: Reconciling the habitat amount hypothesis with the island biogeography theory. Journal of Biogeography, 46(3), 621-632. 
[37] Storck-Tonon D, Silva RJ, Sawaris L, Vaz-de-Mello FZ, Silva DJ and Peres CA. (2020). Habitat patch size and isolation drive the near-complete collapse of Amazonian dung beetle assemblages in a 30-year-old forest archipelago. Biodiversity and Conservation, 29, 2419-2438.

[38] Tourinho AL, Porto W, Benchimol M, Peres CA and Storck-Tonon D. (2019). Marked compositional changes in harvestmen assemblages in Amazonian forest islands induced by a mega dam. Insect Conservation and Diversity, Wiley OnLine Library.

[39] Alho CJR, Conceição PN, Constantino R, Schlemmermeyer T, Strüssmann C, Vasconcellos LAS, Oliveira DMM and Schneider M. (2000). Fauna silvestre da região do rio Manso-MT. Ministério do Meio Ambiente; Edições Ibama; Centrais Elétricas do Norte do Brasil. Brasília.

[40] Mascarenhas BM. (1985). Operação Curupira. Relatório Técnico. Eletronorte, Brasília, DF.

[41] Mérona B, Juras AA, Santos GM and Cintra IHA. (2010). Fishes and fisheries in the lower Tocantins River: Twenty years after the Tucuruí hydroelectric dam. Eletrobras/Eletronorte. Brasília.

[42] Bueno AS, Dantas SM, Henriques LMP and Peres CA. (2018). Ecological traits modulate bird species responses to forest fragmentation in an Amazonian anthropogenic archipelago. Diversity and Distributions, 24, 387-402.

[43] Ferreira LV, Neckel-Oliveira S, Galatti U, Fáveri SB and Parolin P. (2012) Forest structure of artificial islands in the Tucuruí dam reservoir in northern Brazil: a test core-area model. Acta Amazonica, 42(2), 221-226.

[44] Lima AMT, Marques EE, Ertzogue MH, Ferreira DTAM and Lima JD. (2015). Os Rios Amazônicos Convertidos em Gigawatts: Participação Social no Processo de Implantação de Usinas Hidrelétricas . Revista de Administração e Negócios da Amazônia, 7(2), 136-158.

[45] Santos GM. (1995). Impactos da Hidrelétrica Samuel sobre as comunidades de peixes do rio Jamari (Rondônia, Brasil). Acta Amazonica, 25(3-4), 247-280.

[46] Souza Dias V, Pereira da Luz M, Medero GM and Nascimento TFD. (2018). An Overview of Hydropower Reservoirs in Brazil: Current Situation, Future Perspectives, and Impacts of Climate Change. Water, 10(5), 592.

[47] Botelho A, Ferreira P, Lima F, Costa Pinto LM And Sousa S. (2016). Assessment of the Environmental Impacts Associated with Hydropower. Renewable and Sustainable Energy Reviews, 70, 896-904.

[48] Gibson L, Elspeth NW and Laurance WF. (2017). How green is “Green" energy? Trends in Ecology and Evolution, 2306, 1-14.

[49] Kusma CM and Ferreira FW. (2009). Mecanismo de transposição de peixes de pequena central elétrica. Ciência Rural, Online.

[50] Celestino LF, Sanz-Ronda FJ, Miranda LE, Makrakis MC, Dias JHP and Makrakis S. (2019). Biodirectional connectivity via fish ladders in a large Neotropical river. Wiley Online Library.

[51] Deemer BR, Harrison JA, Li S, Beaulieu JJ, Sontro T, Barros N, Bezerra-Neto JF, Powers SM, Santos MA and Vonk JA. (2016). Greenhouse Gas Emissions from Reservoir Water Surface: A New Global Synthesis. BioScience, 66(11), 949-964.

\section{How to cite this article}

Alho CJR. (2020). Hydropower dams and reservoirs and their impacts on Brazil's biodiversity and natural habitats: A Review. World Journal of Advanced Research and Reviews, 6(3), 205-215. 